総説

免疫調節因子 Indoleamine 2,3 - dioxygenase 1 : 創薬のターゲット分子として

\author{
山本 康子 ${ }^{1}$, , 村上 由希 ${ }^{1)}$, 星 雅人 ${ }^{2}$, 斉藤 邦明 ${ }^{1)}$
}

要約 : インドールアミン酸素添加酵素 (Indoleamine 2,3-dioxygenase 1: IDO1） は, トリプトファン (Tryptophan : Trp) をキヌレニン（Kynurenine : KYN）に代謝するキヌレニン経路の律速酵素である. 近年, IDO1 が免疫系に作用することなどから腫瘍細 胞の免疫逃避機構において重要な役割を担っている分 子であると考えられ, 腫瘍での発現量と予後との関係 で注目されている。 また IDO1の活性阻害は, 腫瘍に おける免疫寛容状態の解除など病態と関係する. 本稿 では, IDO1の創薬のターゲット分子としての意義に ついて最近の知見を紹介する.

\section{1. インドールアミン酸素添加酵素（ID01）とは}

トリプトファン（Trp）をキヌレニン（KYN）に代 謝する酵素として IDO1 とトリプトファン酸素添加酵 素 (Tryptophan 2,3-dioxygenase : TDO) が知られて いる．同じ経路を代謝する酵素であるがTDO は主に 肝蔵に存在し生理的なトリプトファン代謝に関与する と考えられている。一方, IDO1 はインターフェロン (IFN) - $\gamma$ などの種々炎症性サイトカインやリポポリサ ッカライドによって酵素誘導され, 抗原提示細胞（樹 状細胞やマクロファージ等) をはじめ上皮細胞や腫瘍 細胞などで強発現する免疫関連分子として, さらには NO との相互作用などで知られる (1).

IDO1 は 1963 年に京都大学の早石博士の研究グル ープによって酸素を直接ベンゼン環に取り込む酸素添 加反応を行う酵素として報告され, その後 1998 年に マウス妊娠中に胎盤での T細胞に関連する免疫応答を 抑制することによる同種抗原の拒絶を防御することか ら注目された (2). 近年, IDO1の構造も決定され, 酵 素のくぼみの中で進行する Trpへの酸素分子添加反応
が, 酵素による水素原子の引き抜きではなく, 二つの 酸素原子と基質の直接反応というこれまで予想されて いなかった独自のメカニズムであることが明らかにさ れている.

IDO1 活性の上昇により Trp より産生される KYNは, さらに下流への代謝産物に分解される. KYN の代謝 経路には，3-ヒドロキシキヌレニン（3HK）から 3-ヒ ドロキシアントラニル酸（3HAA）に代謝される経路, キヌレン酸 (KA) に代謝される経路, アントラニル酸 （AA）に代謝される経路の 3 つが知られている（図 1). これらの代謝産物は生理活性を有し, KA は $\alpha 7$ ニコ チン受容体のアンタゴニスト, 3HK はサイトカイン産 生調節など免疫系への関与が報告されている(3).

\section{2. 種々腫瘍組織における IDO1 発現と予後と の関係}

1950 年頃より種々の腫瘍患者の尿中で $\operatorname{Trp}$ 代謝産 物の増加が報告されていた，腫瘍細胞における IDO1 発現と予後との関倸について肺がん, 乳がん, 肝がん, 大腸がん, 血液腫瘍など様々な検討が行われており, IDO1 高発現症例と予後不良が報告されている.

Uyttenhove らはヒトの大腸がんや胃がんをはじめ とする様々な腫瘍において IDO1 が腫瘍細胞に高発現 していることを見出している(4). 免疫染色による検 討では, IDO1の発現は腫瘍細胞にのみ見られ, 周囲 の間質細胞では発現が認められていない. 腫瘍組織で のIDO1 発現とともに, 抗原提示細胞などの免疫系細 胞においてもIDO1 発現がみられており, メラノーマ, 乳がん, 肺がんなど様々な腫瘍においてセンチネルリ ンパ節での IDO1 陽性細胞が免疫染色レベルで確認さ れている(5).

キーワード：トリプトファン代謝, インドールアミン酸素添加酵素, 免疫寛容

1) 京都大学大学院 医学研究科 人間健康科学系専攻（ T606-8507 京都市左京区聖護院川原町 53)

2) 鈴鹿医療科学大学 保健衛生学部（率510-0293 三重県鈴鹿市岸岡町 1001-1）

E-mail: yamamoto.yasuko.5x@hs.med.kyoto-u.ac.jp＼cjkstart原稿受領日：2013 年 4 月 23 日，依頼原稿

Title: Indoleamine 2,3-dioxygenase 1 modulates the immuneresponse; the new therapeutic targets of this drug

Author: Yasuko Yamamoto, Yuki Murakami, Masato Hoshi, Kuniaki Saito 


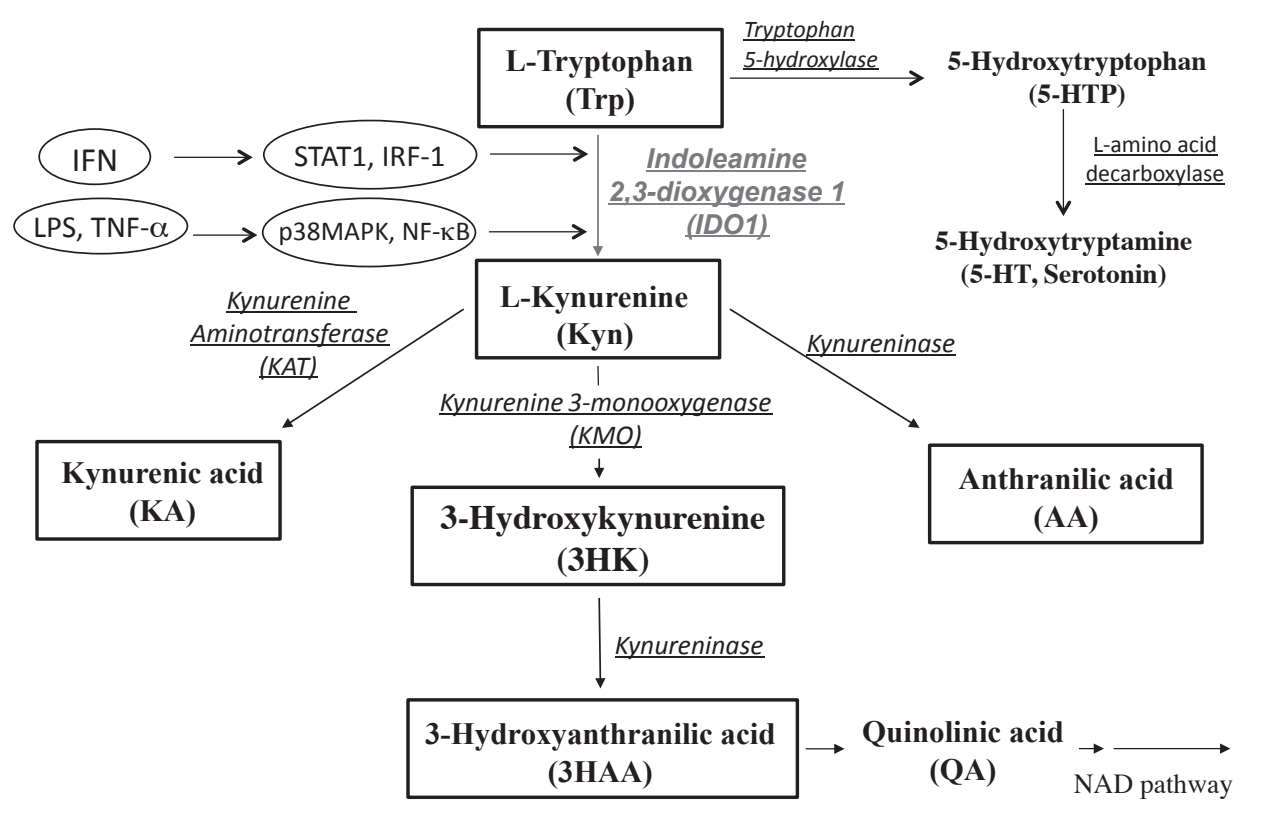

図 1 IDO を基軸としたトリプトファン代謝経路

動物実験モデルを用いた検討も行われ, 腫瘍関連抗 原で前感作されたマウスでは腫瘍を拒絶する腫瘍関連 抗原特異的細胞障害性 T 細胞が誘導されるが, 移植腫 瘍細胞に IDO1 遺伝子を導入すると細胞障害性 T 細胞 に抵抗性を示し，拒絶を免れることが示されている。 また, IDO1 発現は腫瘍組織内への細胞障害性 $\mathrm{T}$ 細胞 数と相関がみられることも報告されており, 細胞障害 性 T細胞の減少はIDO1の阻害薬である1-MT (methyl tryptophan) の投与により抑制される.

Sharma らはB16 メラノーマ担がんマウスの領域リン パ節内には IDO1 を高発現した形質細胞様樹状細胞が 多数存在し，その IDO1の作用により免疫抑制状態を 持続するが, 一旦, IDO1 刺激を遮断すると Th17 細胞 様の形質に変化し免疫抑制能も消失することを報告し ている(6).

我々はこれまでにレトロウイルス感染リンパ腫モデ ル (immunosuppressive murine leukemia virus : LPBM5）において, IDO1 ノックアウトマウスが野生型 に比べ生存率を改善することを明らかにしている。 IDO1 ノックアウトマウスでは, I 型 IFN 産生の増強が みられており, IDO1 抑制がサイトカインの産生に影 響を及ぼす。さらにIDO1 ノックアウトマウスにKYN などの Trp 代謝産物を投与すると野生型と同じ症状を 示すことから, IDO1 の活性上昇に伴う KYN などの代 謝産物の増加が免疫抑制に関与すると考えられる (7).

臨床症例およびマウスモデルを用いた検討において, 腫瘍細胞における IDO1 発現上昇とリンパ組織などに おける免疫系細胞においても IDO1 発現の上昇がみら
れる. 即ち種々の腫瘍患者において IDO1 活性の上昇 により Trp 代謝が充進し, 代謝産物である KYN の血 清中での上昇が認められる，悪性リンパ腫を中心とし た造血器疾患における $\operatorname{Trp}$ 代謝と予後との関係を我々 は検討しており，びまん性大細胞型 B 細胞リンパ腫 （DLBCL）症例における血清 KYN 值の予後因子として の有用性を報告した（8）（図 2)。また肝臓がん再発症 例における血清 KYN 值と予後との関係について, 最 新の検討では, 再発時の KYN 值で予後予測を可能と する知見が得られている.

上述の通りIDO1 は，これまでの多くの研究より腫 瘍の免疫逃避において重要な役割を果たしている分子 であると考えられている. IDO1 が関与する免疫抑制 機構について, 腫瘍細胞自身が発現している IDO1 と 宿主の免疫系の細胞に発現するIDO1, それぞれの機 構について次項で示す.

\section{IDO1 が関与する免疫抑制機構}

\section{1）腫瘍細胞に発現する IDO1による免疫抑制機構}

腫瘍細胞に高発現している IDO1 酵素誘導による結 果として, 腫瘍細胞内および腫瘍細胞周辺での Trp の 枯渴によるストレスが免疫反応を調節していると考え られている. IDO1活性の上昇によりもたらされる $\operatorname{Trp}$ の減少は, 細胞内でのアミノ酸の減少に従って遊 離 t-RNA を増加, さらには GCN2 キナーゼ（general control non-depressive 2 kinase）の活性化をもたらす. IDO1 の活性増加によりもたらされる Trp 枯渇により 腫瘍細胞周辺に存在する $\mathrm{T}$ 細胞は大きな影響をうける. 
つまり， GCN2 キナーゼの活性化により T 細胞は細胞 周期を G1 期に停止させる。.さらに Trp 減少による免 疫抑制機能に加えて, 産生される KYN などの Trp 代 謝産物の影響も示されている，KYNに代表される Trp 代謝産物が in vitroにおいて, T細胞の増殖に関与して いることが明らかとなっており，代謝産物の細胞毒性 により T細胞や NK 細胞などの増殖抑制あるいは細胞 死が誘導される (1)。上述の通り, IDO1 誘導が腫瘍細 胞を攻撃する役割を持つ T細胞の増殖抑制や細胞死誘 導をもたらすことで免疫抑制に働いている（図 3a）.

\section{2）宿主の免疫系の細胞に発現するIDO1による免疫 抑制機構}

宿主の免疫系細胞の中で制御性 $\mathrm{T}$ 細胞（Treg）は腫 瘍の寛容状態の獲得において, 重要な因子の 1 つであ る. Treg の増強は腫瘍の増殖をもたらし, 一方 Treg の減少により腫瘍の抑制効果がみられる. IDO1にお ける免疫抑制作用もTreg と梁く関わっており, Grohmann らは, マウスの樹状細胞において Treg 細胞 が IDO1 の誘導に関与していることを明らかにしてい

a)

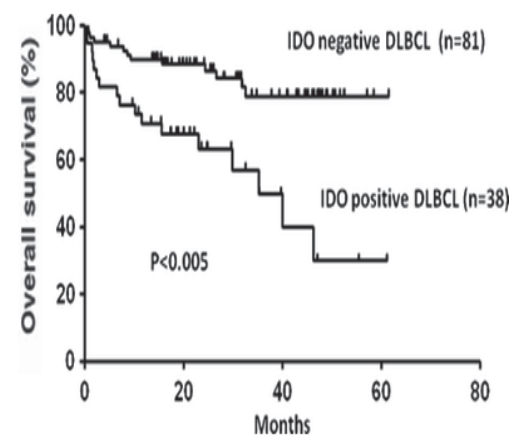

る. Treg 上の CTLA4 と DC 上の B7-1, B7-2b 分子が 結合することで, 樹状細胞に IDO1 の発現が誘導され る. 樹状細胞で誘導された IDO1 はタンパク質レベル での発現も確認され，活性も見られる機能的タンパク 質であることが明らかとなっている(9)。また，ヒト 単球細胞由来の樹上細胞に打いても同様に CTLA4 分 子と B7-1 との結合と IDO1 活性がみられている(10). IDO1の発現細胞は, その形態から宿主の形質細胞様 樹状細胞（plasmacytoid DC）であると考えられている.

最近の in vitroに打ける実験において, IDO1 を発現 した樹状細胞が naive $\mathrm{CD} 4^{+} \mathrm{T}$ cell から新しい Treg の 分化を促進し, IDO1 発現が Treg の増減にかかわるこ とで免疫抑制に働いていることが報告された(11)。こ れらのことから IDO1 発現と Treg は相互に深く関与 していると考えられ, Tregによって発現が誘導された IDO1 がさらにポジティブフィードバックとして働き, Tregの分化を促進させていると考えられる。しかし ながら，樹上細胞上に IDO1 が発現するための一番最 初のトリガーは，樹状細胞とTregの結合であること

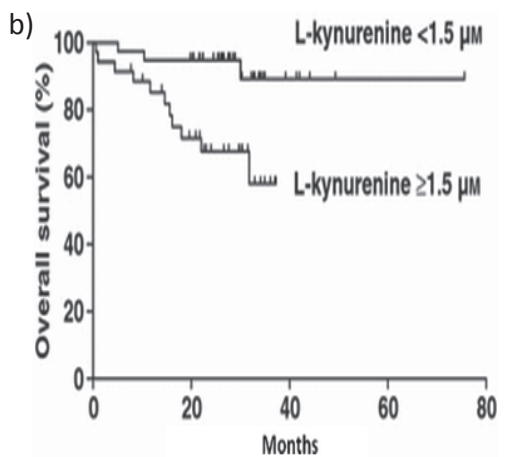

図 2 血液腫瘍における予後マーカーとしての IDOI 発現および代謝産物測定

a) 免疫組織化学染色における IDO1 陽性と生存率との関係，b）血清 KYN 值と生存率との関係. (文献 8 より転載)
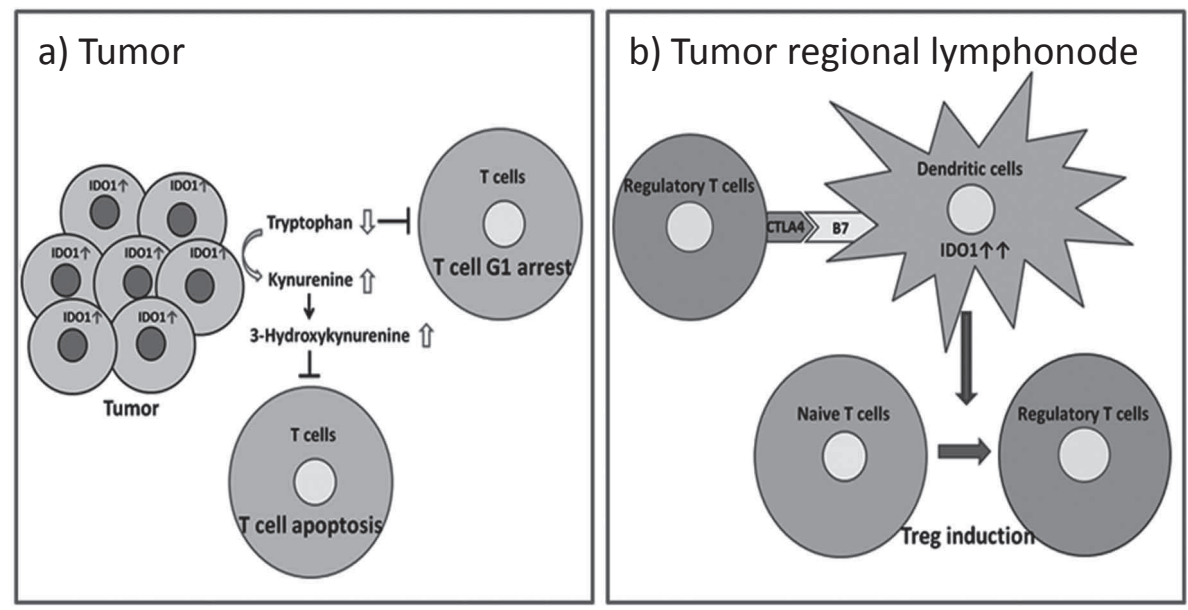

図 3 IDO1 が関与する免疫逃避機構

a）腫瘍細胞に発現するIDOIによる免疫抑制機構，b）宿主の免疫系の細胞に発現するIDOIによる免疫抑制機構。 
も示唆され, 腫瘍において IDO1 が関与する免疫機構 についてはその詳細について今後のさらなる研究結果 が望まれる（図 $3 b ）$.

\section{4. 創薬のターゲットとしての IDO1 阻害薬探索}

腫瘍細胞自身と免疫系細胞における IDO1 発現およ びその誘導は, 前述の通り腫瘍の免疫寛容の成立に深 く関与している．近年 IDO1 活性を抑制することによ る, 腫瘍の免疫寛容状態の解除をターゲットとしてが ん治療効果に期待した IDO1 阻害薬の探索が進められ ている.

実際に免疫抑制因子である IDO1 阻害薬を抗がん薬 などの治療と併用して行うことは予後不良症例におい て有効な効果をもたらすと期待される. IDO1 阻害薬 として研究に沉用されている分子は, 1-MT (1-methyl tryptophan）であり, マウスモデルにおいても1-MT 投与による腫瘍の抑制効果がみられている. Muller らは，トランスジェニックマウスを用いた乳がんモデ ルにおいて1-MT の抗腫瘍効果について検討を行って おり，抗がん薬と 1-MT との併用により抗腫瘍効果の 増強が認められている(12).

米国では, IDO1 の阻害薬である D-1-MT の臨床治 験が始まっている。 しかし, D-1-MT と L-1-MTはそ れぞれでIDO1 抑制効果に差がみられており, L-1-MT の方が IDO1 阻害活性がより強いと報告され ている.さらに動物実験において腫瘍抑制効果の見ら れている D-1-MTは, 培養細胞で IDO1 の活性阻害を 認めないとの報告があり, 阻害薬研究での $\mathrm{D}$ 体, $\mathrm{L}$ 体 による阻害の差に関して, さらなる詳細な検討が必要 である。近年, IDO1 と 45\%のホモロジーを有する IDO2 遺伝子が同定されており, IDO2 は IDO1 に比べ $\operatorname{Trp}$ 代謝活性は低いと考えられるが, 恒常的に脳, 肝
臓，腎臓，精巣上体などで発現している(13)。IDO2 は, 樹上細胞での発現も認められており免疫系への関与も 示唆されるが, IDO2 の生理的役割については今だ不 明な点が多い。臨床治験に進んでいるD-1-MTは, IDO1より IDO2 に対する抑制作用が強いことが報告 されるなど, 1-MT の阻害効果の作用機序については 不明であり, IDO2 の生体内での生理的意義に加え腫 瘍との関係についても今後のさらなる研究が期待され る.

本稿では，IDO1 による Trp 代謝と腫瘍の関係，ま たIDO1 活性や代謝産物測定を用いた疾患の階層化や 予後予測などについて我々の最近の知見も含め紹介し た. IDO1 阻害薬と薬剤の併用による治療効果の改善 などを考えると IDO1 活性の阻害は抗腫瘍において有 効な手段であると考えられる. 即ちIDO1 は創薬の夕 ーゲットであるのみならず, 臨床サンプルの代謝産物 一斉解析による疾患バイオマーカーとしての意義を有 すると考えられ，今後の新しい阻害薬開発も含めさら なる臨床研究に期待したい.

著者の利益相反：開示すべき利益相反はない.

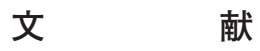

1) Mellor AL, et al. Nat Rev Immunol. 2004;4:762-774.

2) Munn DH, et al. Science. 1998;281:1191-1193.

3) Murakami Y, et al. Mediators Inflamm. 2013;2013:391984.

4) Uyttenhove $C$, et al. Nat Med. 2003;9:1269-1274.

5) Munn DH, et al. J Clin Invest. 2007;117:1147-1154.

6) Madhav D, et al. Blood. 2009;113:6102-6111.

7) Hoshi M, et al. J Immunol. 2010;185:3305-3312.

8) Ninomiya S, et al. Ann Hematol. 2011;90:409-416.

9) Fallarino F, et al. Nat Immunol. 2003;4:1206-1212.

10) Munn DH. J Immunol. 2004;172:4100-4110.

11) Curti A, et al. Blood. 2007;109:2871-2877.

12) Muller AJ, et al. Nat Med. 2005;11:312-319.

13) Fukunaga M, et al. J Histochem Cytochem. 2012;60:854-860. 